\title{
FROM RITUAL TO REALITY: DEMOGRAPHY, IDEOLOGY, AND DECOUPLING IN A POST-COMMUNIST GOVERNMENT AGENCY
}

\author{
ANDRÁS TILCSIK \\ Harvard University
}

\begin{abstract}
Decoupling - the creation of gaps between formal policies and actual practices-is ubiquitous in organizations. Yet little research has examined how decoupling unfolds over time. This qualitative case study of a post-Communist government agency develops process models of what precedes and what follows the decision to decouple. I show that the demography and ideology of powerful organization members influence whether decoupling occurs, how it unfolds, and whether it is sustainable. Further, I suggest decoupling may carry seeds of its own decay: under certain conditions, the decision to decouple can trigger demographic changes that eventually erode decoupling.
\end{abstract}

In institutional theory, decoupling refers to creating and maintaining gaps between symbolically adopted formal policies and actual organizational practices (Meyer \& Rowan, 1977). Decoupling occurs in a variety of organizations. Corporations frequently adopt executive incentive programs that they use only limitedly, or not at all, in practice (Westphal \& Zajac, 1994). Governments create environmental policies but often fail to enforce them (Schofer \& Hironaka, 2005). Schools embrace formal standards symbolically but decouple them from the actual routines of teaching (Meyer \& Rowan, 1978). Even radical social movement organizations adopt socially acceptable procedures and use them to mask their actual, controversial activities (Elsbach \& Sutton, 1992).

Researchers have produced valuable insights into why organizations engage in decoupling. A common theme in this research is that decoupling is a response to institutional pressures-that is, pressures to comply with regulations and norms about how organizations should be structured and operated. In the face of institutional pressures to adopt particular polices or procedures, decoupling allows organizations to signal compliance symbolically without changing their practices substantively (Scott, 2008: 171). Scholars have identified different reasons why an organization might re-

I am grateful to Kim Elsbach and three anonymous reviewers for their insightful suggestions and constructive criticism; to Christopher Marquis for detailed comments on several drafts; to Mary Brinton, Frank Dobbin, Andrea Flores, László Rózsás, and Christopher Winship for helpful discussions; and to my informants and interviewees for their patient cooperation. spond to institutional pressures in this way. According to Meyer and Rowan (1977), decoupling enables organizations to gain external legitimacy while also maintaining the internal flexibility with which it can address practical considerations. For example, a school faced with a government-mandated curriculum that is inappropriate for its students may formally adopt the curriculum to maintain legitimacy but allow actual teaching practices to go on as before in order to address the needs of the students at hand. Building on this framework, Elsbach and Sutton (1992) added that decoupling may help organizational spokespersons provide plausible excuses and justifications in case the violation of an institutional mandate is revealed. More recently, Westphal and Zajac (2001) suggested that decoupling occurs not because it is functional for an organization but because it serves the interests of organizational leaders. For example, a firm may decouple its performance-based executive incentive plan from actual compensation practices because its CEO prefers noncontingent pay (Westphal \& Zajac, 1994).

Although scholars have some insights into why organizations might engage in decoupling, much less is known about how the process of decoupling unfolds over time. In other words, despite the ubiquity of decoupling and its importance to institutional theory, relatively little is known about what leads up to the decision to decouple and what happens inside an organization after that decision. This is a significant omission because a deep understanding of an organizational phenomenon requires examining not only its causes, but also the underlying process by which it unfolds. As Pettigrew noted, process studies are essential for gain- 
ing an appreciation of organizational dynamics, and, therefore, "theoretically sound and practically useful research ... should explore the contexts, content, and process of change together with their interconnections through time" (1990: 268). Thus, treating decoupling as a process, rather than an outcome, and exploring the processes that precede and follow a decision to decouple should extend understanding of this widespread response to institutional pressures. In addition, understanding the critical mechanisms and junctures in the decoupling process may help organizational managers more effectively prevent or bring about decoupling, depending on their goals. Indeed, understanding what happens inside an organization after decoupling occurs may help managers make more informed decisions about how much inconsistency between formal policies and actual practices they should encourage and tolerate.

Accordingly, I set out to investigate two research questions. First, how does the process that leads up to decoupling unfold inside organizations? Second, what happens within organizations over time after decoupling occurs? Although relatively little research has examined these questions directly, existing studies provide important insights on which to build. First, prior research suggests that an interpretive process precedes decisions to decouple: before organization members decide whether to decouple a policy from actual practice, they interpret and evaluate the policy. For example, Coburn (2004) found that, in the face of external pressure to implement new instructional policies, teachers first assessed each new policy through the lens of their prior beliefs and then relied on this assessment to decide whether to adopt the policy only symbolically or in practice as well. Similarly, Binder (2007) found that the extent to which employees of a transitional housing organization coupled their practices with federal funding requirements depended on how they viewed those requirements, which in turn was shaped by their professional commitments.

Second, previous studies suggest that the initially created gaps between policy and practice may not be permanent: that is, policies and practices that were once decoupled may eventually become coupled. Perhaps the first analysis to note this possibility was Espeland's study of the Bureau of Reclamation. Espeland (1998: 94) found that the $\mathrm{Bu}-$ reau's approach to the National Environmental Policy Act gradually shifted from symbolic compliance to actual implementation during the 1970s. More recently, Hallet (2010) noted a similar, although more abrupt, shift in an urban elementary school, where the entrance of a new principal led to the coupling of formerly decoupled policies and practices.

In sum, the existing literature draws attention to several relevant phenomena, particularly the interpretive process that precedes a decision to decouple and the possibility that decoupling is undone in the long run. Previous studies, however, have not explicated a detailed model that outlines the stages through which decoupling unfolds, the conditions that affect whether this process moves from one stage to the next, and the causal and chronological relationships between the various stages of decoupling. This is a significant lacuna because such a model could sharpen existing insights about the decoupling process, help researchers develop testable hypotheses about decoupling in a variety of settings, and deepen understanding of how this widespread organizational phenomenon emerges and develops over time.

To fill this lacuna, I conducted a qualitative case study of a government agency in a post-Communist democracy of the former Soviet bloc. This organization was a suitable research site because it allowed me to investigate how decoupling emerged, how it unfolded over several years, and why eventually the organization ceased to engage in decoupling. More generally, the post-Communist setting was a particularly rich context in which to study how an organization responds to institutional pressures. As the transition from central planning to a market economy produced dramatic institutional changes, it also created an opportunity to explore how organizations embrace or resist fundamentally new institutional pressures (Peng, 2003). Answering my research questions in this setting shed new light on the decision to engage in decoupling and the far-reaching ramifications of that decision. These findings, in turn, have general implications for understanding how institutional forces shape the behavior of organizations.

\section{METHODS}

Qualitative research is useful for building process theories because it is highly sensitive to the context and sequence of organizational events and actions (e.g., Gephart, 2004; Pettigrew, 1990). Case studies, in particular, are well suited to understanding the dynamics within an organization (Eisenhardt, 1989). The case study presented here focuses on a post-Communist government agency. In what follows, I first explain in detail why this particular organization and its broader institutional context provided a useful setting for this study. I then describe how I collected and analyzed data from this organization. 


\section{Research Setting and Context}

The agency. To study decoupling as an evolving phenomenon, I needed a research site where decoupling occurred (or could potentially occur) and where I could conduct a case study over an extended period of time. An organization in which I had previously conducted exploratory research offered both these advantages. This organization, referred to as "the Agency" in this article, is a government agency in a post-Communist democracy in the former Soviet bloc. ${ }^{1}$ The Agency employs approximately 120 employees, who perform several administrative and financial functions, including the oversight of approximately 70 governmentowned subsidiary organizations and the allocation of public funds among them. The subsidiaries provide a set of government-subsidized social services across the country. The funds allocated by the Agency are the primary source of the revenue of the subsidiaries and are used to cover their operating expenses. A simplified organizational chart of the Agency appears in Appendix A.

I first contacted the Agency in 2004 to collect data for a quantitative research project. Originally, I viewed the Agency as a custodian of data about other organizations rather than as a research site. During my first visit, however, I became interested in the Agency itself. Since I was trying to combine fragmented data sets held by different divisions of the organization, this visit exposed me to employees from all hierarchical levels and organizational units. Although I only asked these bureaucrats about statistical data on other organizations, they often told me much more. While describing the nuances of the data, many of them also mentioned their views about the Agency's policies and politics, the regulations that affected their work, and even their colleagues. It was during these conversations that I first heard about discrepancies between the Agency's policies and actual practices in the way public funds were allocated among the subsidiaries. At this time, I also came across a report by a former consultant to the Agency that mentioned the existence of such discrepancies in the late 1990s and possibly later.

\footnotetext{
${ }^{1}$ In agreement with the human subjects committee at my institution, I have concealed the identity of this organization by describing several of its activities and characteristics in general terms and by omitting or, occasionally, slightly altering minor but distinctive information. This kind of protection was necessary because of the legally and politically sensitive nature of the data and the lack of legal guarantees that would protect my informants.
}

These bits of information suggested that the decoupling of financial allocation policies from actual funding practices occurred relatively recently and within the tenure of most organization members. Thus, it seemed that my main phenomena of interest could be plausibly reconstructed or even directly observed (Yin, 1984). In addition, this site offered the promise of long-term access because I had preexisting relationships with some organization members and had already conducted a short research project at the organization. As Pettigrew (1990) noted, both these conditions make it easier to negotiate long-term access to a research site.

Institutional context. In addition to the advantages of this particular site, the wider post-Communist context offered a rich setting in which to study how an organization responds to institutional pressures. In a post-Communist setting, institutional pressures that reflect the logic of capitalism are often exerted on organizations that were created under Communism and are, to this day, run by managers socialized in that context (McCarthy, Puffer, May, Ledgerwood, \& Stewart, 2008). In such settings, an organization and its environment may reflect contradictory institutional logics: whereas the logic of capitalism stresses the primacy of markets and competition, the logic of communism emphasizes bureaucratic coordination and paternalism that shield individuals and organizations from economic forces (Kornai, 1992). This contradiction provides an opportunity to explore how organizations embrace or resist a set of fundamentally new institutional pressures (Peng, 2003).

In addition, a post-Communist context is an especially intriguing setting in which to study decoupling. Under Communism, the managers of state enterprises frequently relied on informal deals and deceptive manipulations-such as the falsification of operational reports-to achieve their goals and those of their organization (Berliner, 1957; Granick, 1961). To the extent that such practices are resistant to change, decoupling and similar phenomena may be relatively common in post-Communist organizations. Indeed, scholars have argued that the uncertainties of the post-Communist transition period may have increased the reliance on informal deals at the expense of formal procedures even further (Ledeneva, 1998; Puffer \& McCarthy, 2007).

\section{Data Collection}

Sample of interviewees. Data collection effectively began in 2004, during informal conversations with Agency employees. I began to collect data more systematically in 2005. To determine the appropriate sample of interviewees, I relied on my 
informants at the Agency to identify all organization members who performed duties related to the allocation of funds among the Agency's subsidiaries. To do so, I asked my informants to describe, as specifically as possible, all the tasks, decisions, and employees involved in making and executing allocation decisions. Appendix B provides the questions asked at this research stage. These conversations yielded a chart of all employees whose responsibilities were directly related to the financing of subsidiaries between 1995 and 2007 (see Appendix $\mathrm{C}$ for this chart in two different years). This group consisted of 19 Agency officers. Since I interviewed 17 of these officers, my sample included nearly all relevant decision makers (89\%). Of the 2 officers I could not interview, 1 had died; the other had retired, and I was unable to locate him. Since I interviewed some respondents more than once, I conducted a total of 23 formal interviews with Agency officers. In addition, I interviewed a member of a government board that oversees the Agency and an economist who served as a consultant to it in the late 1990s. Table 1 lists the interviews by year.

Interviews. The interview protocol appears in Appendix D. The interviews were semistructured and focused on how the Agency allocated funds among its subsidiaries. Since I am fully fluent in the respondents' native language, I conducted the interviews without an interpreter. My outsider status, based on my affiliation with a university in the United States, proved useful because it allowed me to probe interviewees for explanations of their taken-for-granted notions. Indeed, unsure about my familiarity with the nuances of the political environment, many interviewees began their answers by outlining the assumptions that framed their observations.

With the exception of one telephone interview, interviews took place in informants' offices and cafés and lasted between 30 minutes and two hours. I did not tape-record the interviews because of the sensitivity of the subject matter and because I was interested in my interviewees' honest accounts rather than the Agency's official position. Indeed, most informants expressed reluctance about being tape-recorded. Thus, I took notes during each conversation, closely paraphrasing respondents and often abbreviating words to keep up. Whenever possible, I recorded quotes verbatim and underlined them for future reference.

Archival documents. To triangulate the data, I also collected all available public and internal documents directly relevant to the financing of subsidiaries between 1992 and 2006. The public documents included a total of 24 financial reports,
TABLE 1

Summary of Formal Interviews ${ }^{a}$

\begin{tabular}{ll}
\hline Year & \multicolumn{1}{c}{ Position of Interviewee $^{\text {b }}$} \\
\hline 2005 & Statistical coordinator \\
2005 & Senior finance officer \\
2005 & Analyst, statistics \\
2005 & Senior finance advisor \\
2005 & Member of governmental board overseeing the Agency \\
2005 & Associate director, finance (retired) \\
2006 & Associate director, finance \\
2006 & Senior policy officer \\
2006 & Associate director, regulatory affairs \\
2006 & Analyst, program evaluation \\
2006 & Senior economic officer \\
2006 & Economist, former consultant to the Agency \\
2006 & Associate director, subsidiaries (retired) \\
2006 & Associate director, subsidiaries \\
2007 & Senior planning officer \\
2007 & Finance coordinator \\
2007 & Associate director, finance (retired) \\
2007 & Associate director, subsidiaries (retired) \\
2007 & Executive assistant \\
2007 & Analyst, data management \\
2007 & Associate director, subsidiaries \\
2007 & Associate director, finance \\
2007 & Senior finance officer \\
2007 & Senior finance advisor \\
2008 & Senior planning officer (retired) \\
&
\end{tabular}

a This table does not include informal conversations in 2004 or the interviews in 2004 and early 2005 in which I aimed to determine the appropriate sample of interviewees. All listed interviews were semistructured. All were conducted in person, except for the interview in 2008, which was a telephone interview.

$\mathrm{b}$ The position of the interviewee at the time of the interview, or if retired, then position at the time of retirement, is given.

${ }^{\mathrm{c}}$ The person was interviewed for the second time.

policy proposals and analyses, and news releases. The internal documents included a total of 37 memos, internal reports, letters, presentation and meeting minutes, and drafts of public documents. In addition, I obtained the reports of the state accounting office that focused on the Agency's funding practices between 1995 and 2008.

\section{Data Analysis}

Coding. I coded interview notes and archival documents using Atlas.ti, a qualitative data analysis program that allowed me to visualize relationships between different parts of the data and between the data and theoretical ideas (Miles \& Huberman, 1994: 44). I coded the data inductively, looking for emergent themes related to the funding of subsidiaries and any evidence relevant to my research questions: (1) How does the process that leads up to decoupling unfold? and (2) What happens within an organization after decoupling oc- 
curs? In answering the first question, two data sources provided a particularly large number of relevant themes: interview responses to questions 8 and 10 (Appendix D) and internal documents written between 1992 and 1996. In answering the second question, the data sources that proved most relevant included interview responses to questions 11-16 and archival documents written between 1996 and 2008.

I began to code the transcripts using a lexicon of terms used by respondents. As I read and reread the transcripts, I created new codes and adjusted existing ones. To answer the first research question, I coded the text for (1) events and changes that respondents or document authors described as having taken place before the decoupling of financial allocation policies and actual funding practices, and (2) respondents' and document authors' explanations for why decoupling occurred. To answer the second research question, I coded the text for (1) events and changes that occurred after decoupling had taken place, and (2) respondents' and document authors' explanations for these events and changes.

In addition, three other types of codes proved useful in addressing both research questions. First, I flagged each passage with codes indicating the year and month when the event described in the passage occurred. Thus, using Atlas.ti, I could later generate a chronological list of events that occurred in a given period. Second, because the first reading of the data suggested a divergence of opinions about the desirability of decoupling, I coded the text for different opinions on this issue. Third, I coded each interview and document to indicate the respondent's or author's rank, position, and length of tenure at the Agency. Thus, I was later able to examine how different employees varied in their opinions and descriptions of events.

I took two main steps to establish coding reliability. First, I asked an external researcher, also fluent in my informants' native language, to code a random sample of six interviews and 20 documents inductively. This subsample represented approximately 25 percent of the data. Comparing this researcher's codes with mine enabled me to identify recurring topics that I had overlooked and cases in which I had flagged conceptually distinct topics with a single code. Thus, this comparison resulted in an extended and refined coding scheme. Second, I asked another external researcher to code a different random sample of six interviews and 20 documents using my revised coding scheme. Comparing this researcher's codes with mine, I calculated interrater reliability and found high congruence (Cohen's kappa $=.88)$. We resolved discrepancies through discussion, which shed light on a few ambiguities in the coding scheme. After eliminating these ambiguities, I recoded all interviews and documents.

Data matrices. To facilitate the recognition of patterns, I used matrices when organizing data (Miles \& Huberman, 1994). I used Atlas.ti to fill in matrix fields by identifying all instances in which a particular combination of codes occurred. For instance, when examining how employees of different ranks viewed the changes in allocation policies that occurred in 1995, I searched for all quotations describing a "change in policy" in "1995," and then sorted the quotations on the basis of whether they were from "associate directors," "senior officers," or "junior officers."

Two matrix types were particularly useful. First, a role-ordered matrix (Miles \& Huberman, 1994: 122) allowed me to detect convergence and divergence in the opinions and event descriptions of different actors; a condensed version of this matrix appears in the Findings section. Organizing the data in this way was especially helpful in answering the second research question because it helped reveal the motivations for different actions that took place in the aftermath of decoupling. Second, I used a time-ordered matrix (Miles \& Huberman, 1994: 119) to organize events in a chronological sequence. A simplified version of this matrix also appears in Findings. This display allowed me to visualize when particular changes took place. For example, I used this matrix to detect gradual shifts in the size of different groups inside the Agency. This matrix was highly relevant to both research questions because it revealed how changes unfolded over time, both before and after decoupling.

Evaluation of evidence. Throughout the analysis, I cross-checked claims by interviewees against the archival sources. For example, when a respondent mentioned a particular meeting, I looked for transcripts and presentation slides from that meeting. Likewise, I regularly compared informants' views expressed in the interviews with the contents of documents they authored. Finally, I crosschecked my informants' claims against reports of the state accounting office, which described the Agency's financial policies at different points in time. These triangulation strategies helped me gain a more secure understanding than a single data source would have allowed (Maxwell, 1996).

With several iterations between the data and my emerging models, I developed a timeline to capture the chronological and causal relationships among different events in the decoupling process. The comparison of this working framework to the data led me to retain, modify, or abandon each of the 
"hunches" that my initial exposure to the Agency had inspired (Miles \& Huberman, 1994). Thus, I developed increasingly explicit models of the processes that preceded and followed decoupling. The next stage of the analysis was to evaluate the strength of evidence for these models (see tables below). I defined evidence as strong when it was consistent both across and within my two main data sources: interviews and archival documents. Thus, I inferred strong evidence for an aspect of a model when many examples as well as clear and consistent descriptions in several different documents and in the narratives of many informants substantiated it. I considered evidence to be moderate when it was clearly and consistently supported in either the interviews or the documents, but not both.

I now turn to the findings that emerged from this analysis. First, in the Findings section, I describe how decoupling emerged, unfolded, and came to an end in the case of the Agency. Then, in the Discussion section, I develop general theoretical models of these observations.

\section{FINDINGS}

Two research questions guided my research. First, how does the process that leads up to decoupling unfold inside organizations? Second, what happens within organizations over time after decoupling occurs? Accordingly, this section is divided into two parts. I first document the events that led up to the decoupling of formally adopted funding policies and actual allocation practices in the Agency. Then, I describe the events that unfolded in the aftermath of decoupling and how these events eventually led to the erosion of decoupling.

\section{The Road to Decoupling}

My analysis revealed evidence for the decoupling of formal policies and actual practices in the way the Agency allocated funds among its subsidiaries between 1995 and 2005. The path to decoupling can be summarized as follows: During the Communist era (from the late 1940s to 1990), the allocation of funds among the subsidiaries depended largely on the discretionary decisions of the Agency's powerful bureaucrats. This allocation system persisted even after the fall of Communism in 1990. From the early 1990s, however, the Agency came under pressure to abandon this funding model and to adopt a more transparent system using a mathematical formula to determine how much funding each subsidiary should receive. A group of powerful bureaucrats in the Agency believed that formally adopting this new model was necessary for preserving organizational legitimacy. At the same time, for ideological reasons, these bureaucrats resisted the implementation of this model in practice. Since these bureaucrats had control over the relevant organizational domain at the time, they were able to preserve the discretionary system in practice while symbolically adopting the formula-based model. Table 2 summarizes the evidence for these propositions, and I elaborate this evidence below.

Institutional pressures for change. During the Communist era, the Agency used a highly discretionary form of incremental budgeting to determine the allocation of funds among the subsidiaries. Each year, the subsidiaries received a budgetary base equal to their funding in the previous year and an additional increment, which was determined at the discretion of the Agency's officers. As a senior officer who joined the Agency in the early 1980s explained: ${ }^{2}$

[All subsidiaries] received sufficient funding to cover their expenditures because [each year] they got at least as much as in the previous year. And if we judged that [a subsidiary] was especially disadvantaged or deserving-if they had a demonstrated need for more funding-then we gave them more funding.

This funding model persisted even after the fall of Communism in 1990. By the mid 1990s, however, such systems came under increasing criticism from several sources: (1) policy analysts who commented on post-Communist reforms in academic and journalistic publications, (2) economists who advised government organizations, and (3) international nongovernmental and intergovernmental organizations, including the World Bank and the International Monetary Fund, which provided policy advice to post-Communist governments. The main criticism was that discretionary funding systems led to an arbitrary distribution of funds, determined by planners' conception of need and quality, rather than by actual costs or performance. Thus, critics recommended the replacement of incremental budgeting with a more equitable and transparent allocation system. Many critics specifically called for a so-called algorithmic or formula-based system, which uses statistically determined standards

\footnotetext{
${ }^{2}$ Interview excerpts are closely paraphrased accounts of the interviewees as they appear in my interview notes; underlined phrases are verbatim quotes from the interviewees. Archival documents and e-mail messages from respondents are quoted verbatim throughout.
} 
TABLE 2

The Road to Decoupling

\section{Proposition}

Evidence $^{\mathrm{a}}$

Strong (19)

1. Discretionary budgeting practices that began in the Communist era survived even after 1990.

2. From the early 1990s, the Agency experienced institutional pressures to abandon discretionary practices.

Strong (22)
Strong (16)

3. The Old Guard of the Agency believed that formally adopting the algorithmic system was necessary to maintain the Agency's legitimacy.

4. The Old Guard had ideological reasons to preserve the discretionary system in practice.

5. The Old Guard had ideological reasons to focus on maintaining their control over subsidiary finance rather than another organizational domain.

6. In the mid 1990s, the Old Guard had control over the allocation of funds among subsidiaries.

7. In the mid 1990s, the Agency symbolically adopted an algorithmic system, but discretionary practices survived to a large extent.

\section{Examples $^{\mathbf{b}}$}

Interview: "We have used incremental budgeting since I came here [in the early 1980s] and continued to use it after the changes in '89 and '90." (retired senior planning officer)

Archival: "In the first half of the 1990s, fund distribution has remained to be based on annual ad hoc decisions about the proper allocation." (internal report from 2000 reviewing the history of funding practices at the Agency)

Interview: "Starting with the transition [from communism], there has been an expectation from outside to change this system.... We heard it from politicians and economists all the time. Journalists would ask about it. . . . Reports from the IMF and World Bank talked about it." (retired associate director)

Archival: "It is now evidently an expectation from a governmental and parliamentary level and from the World Bank to modernize allocation systems in the public sector. ... A reform of our current systems is inevitable." (1995 internal memo)

Interview: "Not changing [the budgeting system] would have appeared completely inappropriate then. It would have opened [the Agency] to a lot of criticism. ... We would have had a lot of explaining to do." (retired associate director)

Archival: "Undoubtedly, to preserve our credibility and to protect the reputation and public relations of [the, Agency], we must move toward a formula-based system." (1995 internal memo)

Strong (21) Interview: "They are a different generation. They believe we have to save the state's assets, [that] we have to nurture them. That's why they did it." (senior economic officer, discussing why the Old Guard preserved discretion over a portion of funds)

Archival: "Our organization has an obligation to protect the country's property. If we give up control over funding, we cannot fulfill it." (internal memo by retired associate director, member of the Old Guard)

Moderate (14) Interview: "You can't control everything-it's a give and take. But the funding [of subsidiaries] was always a priority because we believe [the subsidiaries] have to be protected. That's not up for negotiation." (senior finance advisor, member of the Old Guard)

Interview: "Saving the [subsidiaries] at all cost was really part of this old paternalistic mentality. ... They were more flexible about other things but they were just very stubborn about this." (associate director, describing the Old Guard)

Moderate (19) Interview: "They [the Old Guard] were very strong back then. They had all the important positions. ... Nobody would challenge them." (associate director, recalling the situation in 1995)

Interview: "We made a decision and that was it. Our colleagues didn't second-guess it. . . . Why would they question it?" (senior finance advisor, a member of the Old Guard, recalling the process of fund allocation in 1995)

Strong (18) Interview: "Some of the funds were distributed with the formula but we also set aside some of the funds so they could be given to the most needy [subsidiaries]." (senior policy advisor)

Archival: "18 months ago, an [algorithmic] system was created and launched. . . . Unfortunately, a large portion of our funds still does not go through this system." (1997 internal memo from a group of young employees urging an algorithmic system)

\footnotetext{
${ }^{\text {a }}$ I defined evidence as strong when it was consistent both within and across the interviews and documents. I considered evidence as moderate when it was consistently supported by clear examples and descriptions in either the interviews or the documents, but not both. The figure in parentheses indicates the number of interviews (out of 25) in which the interviewee clearly mentioned the theme.

${ }^{\mathrm{b}}$ Interview excerpts are closely paraphrased accounts of the interviewees as they appear in my interview notes. Documents are quoted verbatim.
} 
for the allocation of funds. Under this system, funding levels are calculated using a formula that multiplies workload measures (such as number of customers) by a corresponding cost rate. Responding to a follow-up e-mail after an interview, a statistical analyst at the Agency used an example to explain how such systems work:

Let's say you are funding bus companies. Then, a very simple formula would multiply the kilometers traveled by the cost of gasoline per kilometer, and that's how much money you would give [to each bus company]. ... Of course, in reality, you may include many more factors in the formula, like the number of customers, the estimated salary of drivers, maintenance costs per kilometer, and so on. ... Once the formula determined the level of funding, there is no way to re-negotiate anything, so if [a company] is expensive and inefficient, it couldn't cover its costs.

As this analyst noted, a key purpose of algorithmic budgeting is to create incentives for cost-effective operation. Under this system, subsidiaries that consistently operate at a high level of costs would experience difficulties in covering their expenses. Thus, unless these high-cost organizations found ways to cut costs or to generate revenues in addition to their funding from the state, they would be forced into insolvency.

The Old Guard. In the mid 1990s, most of the Agency's managers were older, experienced bureaucrats who had begun their careers at the Agency or another government organization during the Communist era. Many of them rose to important positions in the state bureaucracy in the 1980s and weathered the wind of change brought by the transition to a market economy in the early 1990s. I call this group the "Old Guard" of the
Agency. Table 3 summarizes evidence supporting this categorization.

In 1995, the Old Guard reluctantly decided to adopt an algorithmic budgeting system. Although these bureaucrats thought that formally adopting an algorithmic system was necessary to preserve the Agency's legitimacy, they also believed that implementing algorithmic budgeting in practice would jeopardize the Agency's ability to fulfill its duties. In a typical comment, a member of the Old Guard explained:

In the '90s politicians and the World Bank wanted huge changes in how we run state organizations. Funding systems like ours were a target for many [and] we had to satisfy these critics. Politically, it was important for [the Agency] to look modern and progressive. But we never believed that [algorithmic] budgeting would work in practice.... Taking it on was a compromise-good politics but bad practice.

This skepticism toward algorithmic budgeting was rooted in the Old Guard's ideology-the group's shared ideas, values, and beliefs-according to which it was the duty of state bureaucrats to assume a caring role and to preserve all organizations that operated under the oversight of the state. In the case of the Agency, this view implied an unconditional obligation to ensure the survival of each and every subsidiary: if a subsidiary was in financial trouble, the Agency had to stand by it and save it from bankruptcy. An algorithmic system, however, would limit the Agency's ability to fulfill this obligation because it threatened to drive high-cost subsidiaries to insolvency. As another member of the Old Guard noted,

TABLE 3

Role-Ordered Matrix: Major Groups within the Agency ${ }^{a}$

\begin{tabular}{|c|c|c|c|c|c|c|c|}
\hline \multirow[b]{2}{*}{ Group } & \multicolumn{3}{|c|}{ Demographic Characteristics } & \multicolumn{4}{|c|}{ Ideology } \\
\hline & $\begin{array}{c}\text { Age in } \\
1990\end{array}$ & Higher Education & Pre-1990 Career & Duty of the Agency & How to Perform Duty & $\begin{array}{l}\text { Insolvency of a } \\
\text { Subsidiary }\end{array}$ & $\begin{array}{l}\text { Opinion of Other } \\
\text { Group }\end{array}$ \\
\hline Old Guard & $\begin{array}{l}\text { 40-55 } \\
\text { years }\end{array}$ & $\begin{array}{l}\text { Degree in political } \\
\text { science or } \\
\text { another social } \\
\text { science, earned } \\
\text { typically in the } \\
\text { 1960s }\end{array}$ & $\begin{array}{l}\text { Work at the Agency } \\
\text { or elsewhere in } \\
\text { the Communist } \\
\text { state bureaucracy }\end{array}$ & $\begin{array}{l}\text { Ensure the survival } \\
\text { of all } \\
\text { subsidiaries }\end{array}$ & $\begin{array}{l}\text { Incremental budgeting } \\
\text { system with high } \\
\text { level of } \\
\text { discretionary } \\
\text { spending }\end{array}$ & $\begin{array}{l}\text { Loss of valuable } \\
\text { national } \\
\text { property }\end{array}$ & $\begin{array}{l}\text { "Technocrats" with a } \\
\text { "neoliberal } \\
\text { mentality" who } \\
\text { are "insensitive" } \\
\text { to the country's } \\
\text { needs }\end{array}$ \\
\hline Reformists & $\begin{array}{l}20-30 \\
\text { years }\end{array}$ & $\begin{array}{l}\text { Degree in } \\
\text { statistics, } \\
\text { econonometrics, } \\
\text { computer } \\
\text { science }\end{array}$ & $\begin{array}{l}\text { None, or entry-level } \\
\text { job at a } \\
\text { government } \\
\text { organization }\end{array}$ & $\begin{array}{l}\text { Ensure the efficient } \\
\text { and cost- } \\
\text { effective } \\
\text { functioning of } \\
\text { subsidiaries }\end{array}$ & $\begin{array}{l}\text { Efficiency-driven } \\
\text { restructuring } \\
\text { through transparent } \\
\text { and nonnegotiable } \\
\text { formula }\end{array}$ & $\begin{array}{l}\text { Natural result of } \\
\text { efficiency- } \\
\text { driven } \\
\text { selection }\end{array}$ & $\begin{array}{l}\text { "Old comrades" with } \\
\text { an "old } \\
\text { paternalistic } \\
\text { mentality" }\end{array}$ \\
\hline
\end{tabular}

${ }^{a}$ The original matrix also showed individual-level information within each group. For simplicity, and because there was high convergence within the groups, this display does not contain that information. 
TABLE 4

Time-Ordered Matrix ${ }^{\mathrm{a}}$

\begin{tabular}{|c|c|c|c|c|}
\hline & 1990-1995 & 1995-2000 & 2000-2005 & After 2005 \\
\hline Formal policy & $\begin{array}{l}\text { Incremental budgeting with high } \\
\text { level of discretionary } \\
\text { spending }\end{array}$ & Algorithmic budgeting & Algorithmic budgeting & Algorithmic budgeting \\
\hline Actual practice & $\begin{array}{l}\text { Incremental budgeting with high } \\
\text { level of discretionary } \\
\text { spending }\end{array}$ & $\begin{array}{l}\text { Partially algorithmic } \\
\text { system with high } \\
\text { level of } \\
\text { discretionary } \\
\text { spending }\end{array}$ & $\begin{array}{l}\text { Partially algorithmic } \\
\text { system with high } \\
\text { level of } \\
\text { discretionary } \\
\text { spending }\end{array}$ & Algorithmic budgeting \\
\hline Old Guard & $\begin{array}{l}\text { Occupied senior-level and } \\
\text { associate director positions }\end{array}$ & $\begin{array}{l}\text { Occupied senior-level } \\
\text { positions; formally } \\
\text { introduced } \\
\text { algorithmic system } \\
\text { in } 1995\end{array}$ & $\begin{array}{l}\text { Experienced wave of } \\
\text { retirements }\end{array}$ & $\begin{array}{l}\text { Only few members } \\
\text { left at the Agency }\end{array}$ \\
\hline
\end{tabular}

\footnotetext{
a The original matrix showed information per year; to demonstrate major trends more succinctly, this display focuses on five-year
} intervals.

The state must intervene to protect the country's valuables. .. . Our job is to ensure the proper functioning and survival of all the subsidiaries. That is the duty of this organization. But an [algorithmic] system can't do that. It punishes subsidiaries that produce at a high cost-it drives them to insolvency. ... The problem is that a rigid, automated formula can't take into account every important difference between subsidiaries. ... A formula might punish a subsidiary because [the formula's creators] didn't understand the situation of that subsidiaryall its costs, all its problems.

For the Old Guard, ensuring the survival of the subsidiaries by resisting the algorithmic system was not just one of many political issues; it was a way to enact their vision of public service and to fulfill what they saw as their duty. As a member of the Old Guard explained:

We always felt very strongly about the survival of [the subsidiaries]. We believe it is a very important cause for the country. ... . [The 1990s] were turbulent times, and we had many important, life-ordeath political battles to fight. But we were committed to protecting the [subsidiaries]. It was a way to do something good. . . . We preserved the country's valuables.

Similarly, another member of the Old Guard explained that it was much more important to pre- serve discretion over the funding of subsidiaries than over other areas:

In the ' 90 s we readily gave up control of many areas where our judgment was less important. But [the funding of subsidiaries] was important . . . we cared about [the subsidiaries] . . . we wanted to save them. ... I don't know how closing a [subsidiary] could be efficient. ... Helping them survive is sound management of national wealth.

As this interviewee emphasized, what made the funding of subsidiaries more important than other organizational domains was the strong sense of duty that the Old Guard attached to the preservation of subsidiaries:

[In the 1990s] changes were happening in everything-staff recruitment and training, the legislative proposal process, research, monitoring, public relations, international relations, and so on. . . . Everything was changing and we couldn't keep up with everything. But [subsidiary] finance was too important to let go. It affects whether we can do our duty. . . . If you don't control the funding, there is no guarantee you can preserve [the subsidiaries].

Even the Old Guard's rivals confirmed the importance of ideology in the Old Guard's resistance to algorithmic budgeting. The following excerpt is from an interview with an analyst who joined the 
Agency in 1995 and has been critical of incremental budgeting ever since:

Respondent: They think we need all of [the subsidiaries]. ... They gave up their omnipotence in other things but this was such a big thing for them....

Interviewer: Could [the Old Guard] have hidden motives?

Respondent: I believed so in '95. ... I thought maybe they had old connections to the leaders of some [subsidiaries] from back in the old days. But most [subsidiaries] got a new leadership in the first half of the '90s.... If this was about something like that, we would know. In ten years I never came across any evidence for that. I hoped I would but I didn't. ... It's their conviction so it's even more frustrating - so much ado about an outdated idea.

Decoupling. In sum, although the Old Guard recognized that adopting the algorithmic system would help to maintain organizational legitimacy, they regarded the preservation of subsidiaries as an important duty and viewed the algorithmic system as a threat to fulfilling that duty. Thus, under the Old Guard's leadership in the mid 1990s, the Agency decoupled the formally implemented algorithmic system from its actual allocation decisions. Although an elaborate set of algorithmic funding procedures was adopted to derive the annual budget for each subsidiary, the Old Guard had no intention of fully implementing this system in practice.

At that time, no one stood in the way of this decision. As an analyst who joined the Agency in 1995 noted, the Old Guard enjoyed uncontested control over the allocation of funds in the mid 1990s:

Everything was in their hands then. ... Whatever they wanted to do about [subsidiary] financing, it would happen. There was no opposition at all... . They managed the funds, they kept the accounts, they wrote the rules.

Consequently, the Old Guard was able to decouple the algorithmic system from actual funding practices without encountering any significant resistance. In doing so, they subjected only a portion of the subsidiaries' funds to the algorithmic formula and preserved control over the remainder of the funds, which they then distributed at their discretion. Consequently, algorithmic budgeting was formally implemented but, in essence, a highly discretionary form of incremental budgeting survived as the key allocation mechanism. Discussing funding practices in the second half of the 1990s, a statistical analyst explained:
It was easy to circumvent the formula then. There was a lot of money floating around [in the Agency], money for long-term development, for emergencies, ad hoc purposes, and all kinds of unclear purposes. All those funds weren't distributed through the formula.... So, when the formula didn't produce the numbers that [the Old Guard] wanted, they gave more of those floating funds to the [subsidiaries] that didn't get enough money [in their opinion]. . . . But official public reports of [subsidiary funding] showed only the amount that came from the formula. The other, additional funds were reported in a bunch of fragmented, obscure documents. ... So it would have been very difficult to discover the manipulation.

Quantitative data confirmed this account. In 2007 the state accounting office retrospectively pulled data from the above-mentioned fragmented documents and reported the aggregate data. Thus, I was able to compare the actual amount that each subsidiary received with the amount that the formula prescribed. This comparison revealed that, in the late 1990s and early 2000s, nearly 40 percent of all funds were distributed independently of the algorithmic system. Though a few subsidiaries received the precise amount determined by the formula, some others received nearly three times as much as the algorithmically derived amount. On average, the deviation from the algorithmically derived sum was nearly 60 percent, but the size of the deviation ranged widely across subsidiaries-from 0 to almost 200 percent. $^{3}$ Thus, there was little systematic relationship between the algorithmic sums and actual funding levels. As the above-quoted analyst noted,

The share of the pie [that each subsidiary received] under formula funding was very similar to [what it was under] the old [discretionary] system. . .The formula was a Potemkin village. It was a mask. . . . The old system lived on.

${ }^{3}$ To give a simple example, the algorithmic system may allocate the equivalent of $\$ 60,000$ to a subsidiary, but bureaucrats would decide whether that subsidiary should receive, say:

(1) no extra funds (total is $\$ 60,000$, so 100 percent of the prescribed sum, i.e., 0 percent deviation from the formula), or

(2) $\$ 35,000$ extra funds (total is $\$ 95,000$, so 158 percent of the prescribed sum, i.e., 58 percent deviation from the formula), or

(3) $\$ 120,000$ extra funds (total of $\$ 180,000$, so 300 percent of the prescribed sum, i.e., 200 percent deviation from the formula). 


\section{The Aftermath of Decoupling: The Changing of the Guard}

The changes that occurred in the aftermath of decoupling can be summarized as follows. The formal adoption of the algorithmic system necessitated hiring employees with the skills for producing symbolic documents of compliance. Unlike the Old Guard, however, these new organization members saw algorithmic budgeting as a useful tool and were committed to putting it into practice. By rising in the organizational hierarchy and building alliances, these new actors gradually accumulated power in the Agency and were able to put the algorithmic system into practice in 2005. Thus, ironically, the actors who did away with decoupling were the very employees whom the Agency had originally hired for merely symbolic reasons. Table 5 summarizes the evidence for these propositions, and I elaborate this evidence below.

Enter the Reformists. Trained in economics, statistics, and computer science, a group of young technocrats-whom I call the "Reformists"-joined the Agency when the algorithmic system was formally introduced (see Tables 3 and 4). At that time, the ostensible purpose of recruiting these new employees was to hire experts who would put the formula-based system into practice. In reality, however, the Old Guard intended the work of these young bureaucrats to be largely symbolic. In a typical comment, a Reformist interviewee explained:

We were told that our main task would be to run [an algorithmic system]. But much of the money was distributed independently [of this system]... . Our calculations showed up on paper, but they did almost nothing in practice.... Our supervisors distributed so much money outside our system. ... We kept offering to build all that money into the system but they ignored us.

The Reformists brought a radically new view of fund distribution to the Agency. Unlike the Old Guard, they saw no reason to ensure the survival of the subsidiaries. They believed, instead, that the Agency should put fiscal pressure on high-cost subsidiaries, thereby forcing them to manage their resources more efficiently. This position fit into a broader view in which the duty of state bureaucrats is to promote efficiency in the public sector through incentives and marketlike mechanisms. As a Reformist interviewee noted,

The old incremental system softens the budget constraint. ... It's a suboptimal resource-allocating mechanism. It distorted the incentives. ... But the question is: how can we make [the subsidiaries] more efficient? . . . The [funding] system has to be an uncompromising selection mechanism. It has to be a quasi-market. ... The subsidiaries with a high average cost should fail.

These young employees had little patience for the Old Guard. As a Reformist analyst explained,

I believe statistical analysis can make the state administration more enlightened. It is very transparent and impartial. But they have no clue of what [quantitative] modeling can accomplish. ... They are a bunch of old comrades. ... They have this entrenched communist, paternalistic mentality. We always wanted progress and modernization but they had completely different values and views.... . Once I saw one of those old comrades allocate a ton of money with a pen on a sheet of paper. You can imagine my shock and dismay.

Members of the Old Guard were similarly dismissive of the Reformists' ideas. For example, a retired associate director described the Reformists as:

Technocrats who are good at data [manipulation] ... But they don't understand the big picture, ... They are insensitive to what the country and the [subsidiaries] need.... They don't understand the interests of the country.

The Old Guard recognized the ideological roots of the Reformists' resistance to incremental budgeting. Indeed, as several members of the Old Guard noted, understanding the Reformists' "neoliberal" ideology was essential for understanding why these new employees insisted on a fully algorithmic system. As one member of the Old Guard explained,

They had good jobs but they were subordinates [so] we didn't expect that they would turn against us [and] try to usurp the whole system. At first, we didn't know that they would look at everything with this neoliberal mentality. ... They are fixated on running everything like a business. But [public] administration is not a business.

Until the end of the 1990s, however, the Reformists were a relatively small group with neither direct representation nor powerful allies in the Agency's senior management. Although members of the Old Guard held prestigious, influential positions as associate directors and senior officers, the Reformists occupied junior-level positions as analysts and coordinators (see Appendix C). Thus, year after year, the Old Guard was able to realize its vision of a rational funding system without encountering significant resistance. As a Reformist interviewee recalled,

We tried to pitch a fully formula-based system. We tried every year. But this was not taken seriously. We were simply ignored. . . It went like this until 2003, 2004 . 
TABLE 5

The Aftermath of Decoupling

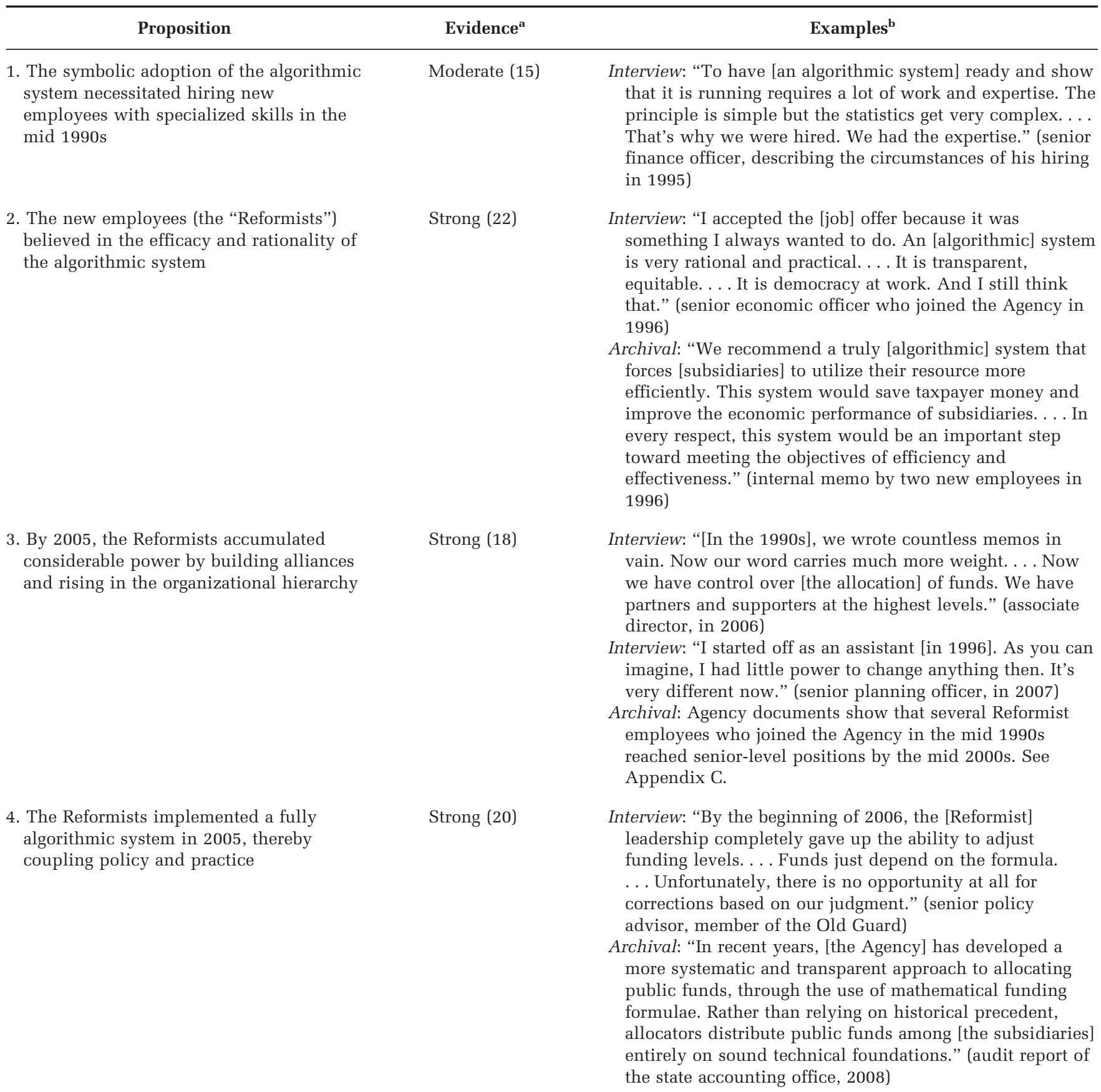

${ }^{a}$ I defined evidence as strong when it was consistent both within and across the interviews and documents. I considered evidence as moderate when it was consistently supported by clear examples and descriptions in either the interviews or the documents, but not by both. The figure in parentheses indicates the number of interviews (out of 25) in which the interviewee clearly mentioned the theme.

${ }^{\mathrm{b}}$ Interview excerpts are closely paraphrased accounts of the interviewees as they appear in my interview notes. Documents are quoted verbatim.

The Agency's internal documents confirmed this account. In a series of internal reports and memos produced between 1997 and 2003, the Reformists urged a truly algorithmic system, but these pleas failed to elicit any response that was recorded in writing.
The Reformists' rise to power. Between 2000 and 2005, the Reformists accumulated considerable power within the Agency. Two changes played a critical role in this process: (1) the Reformists took over key decision-making positions from the Old Guard and (2) they built powerful alliances in the Agency. 
In the early 2000s, several members of the Old Guard reached the official age of retirement and had, therefore, no choice but to leave the Agency. The gradual departure the Old Guard opened promotion opportunities for the Reformists, creating a vacancy chain (White, 1970) that reshaped the demography of the actors who had control over the funding of subsidiaries. As a Reformist interviewee noted,

[The Agency] usually promotes people from within. ... When senior people who have been here since the '80s or earlier started to leave, there were usually only younger employees who could be promoted to fill the vacancy. And [these young persons'] former jobs went to other young people. So, when someone older left, that often meant two promotions for younger people.

As a result, several Reformists who had been at the Agency since the mid 1990s climbed higher on the promotion ladder. At the same time, the Old Guard was gradually losing ground. As one of them explained,

Every year someone important from my generation retired. They reached the mandatory [retirement] age.... Younger employees stepped in their place. . . It was like a spiral. There were fewer and fewer of us, so there was less and less commitment to preserve the traditional values [of the Agency].

A comparison of the list of officers in the late 1990s and a decade later confirms these accounts. In 1997, all seven senior-level and associate director positions with direct control over the funding of subsidiaries were filled by people who had joined the Agency before 1990. By contrast, in 2007, all but two such positions were filled by employees who joined the Agency after 1995 (see Appendix C).

In addition to rising in the organizational hierarchy, the Reformists also built important alliances in the Agency. Reformist interviewees noted the importance of shared ideology in securing these alliances. In a typical comment, a young analyst explained:

Young employees in other divisions of the Agency were attracted to our ideas not only because of our similar age and position in the hierarchy. ... We all studied some economics ... so we knew about the problems with bailing out inefficient organizations, the problem of soft budget constraints. These ideas only began to seep into the state bureaucracy, but they gave [younger employees] a common language. ... [The Old Guard] didn't have such a common language with people below them [in the hierarchy].
In addition to winning the support of young Agency employees, the Reformist enlisted two newly appointed high-ranking officers (a senior adviser and an associate director) as supporters of a fully algorithmic system. These appointees had built successful careers outside the Communist state bureaucracy and did not share the Old Guard's unflinching commitment to the preservation of every subsidiary. Instead, they evaluated policy options on the basis of their potential to streamline the Agency's operations. As one of these appointees remarked,

I came from the private sector.... I know little about public finance and modeling. But [an algorithmic system] seemed like a good idea. It is straightforward and practical. It doesn't require reinventing the wheel every year. ... Once it's in place, it can be run without too much tinkering.

A Reformist interviewee explained how he and his colleagues "pitched" the algorithmic system to these new organization members:

They cared about making things less complicated, less cluttered. They wanted less red tape.... [So] we pitched our model to them as a timesaving, simplifying tool. We explained how it makes things more streamlined, more systematic.

At the same time, the two new appointees reported that no one from the Old Guard tried to convince them of the efficacy of incremental budgeting. Thus, gradually, both new appointees came to view an algorithmic system as the most desirable solution. This was an important boost to the Reformists' efforts because, even among senior leaders, the two new appointees had significant organizational and political power. As a Reformist analyst explained,

Their support was very important to us. It gave us credibility in everyone's eye in the Agency.... Their respect counts because they have some very important allies in other [state agencies]. And they have good connections to people of the highest rank in politics.

Coupling policy and practice. The Reformists' rise in the Agency's hierarchy and their new alliances were critical in introducing a fully algorithmic system in practice. As associate directors and senior officers, the Reformists gained direct control over the distribution of public funds among the subsidiaries. In addition, thanks to their alliances, they were also able to prevent the Old Guard from mobilizing the Agency's highest-ranking officers against the algorithmic system. As a Reformist statistical coordinator noted,

There was a lot of turnover. . . . So, by 2005, we were in more important positions and had much more 
authority over the various funds flowing [to the subsidiaries] than before.... We began to build those funds into [the algorithmic system]. . . . I think those who were against this hoped there would be a phone call from upstairs to stop. ... But they couldn't go behind our backs to lobby against the system . . . because our model has supporters everywhere, even high up.

At the same time, the few remaining members of the Old Guard became increasingly isolated. As one of them explained,

By [the mid 2000s], we resorted to finding supporters [for incremental budgeting] among young rivals of [the Reformists] in other parts of the Agency. . . . But these young people were all supporters of a marketlike process.... So, we tried to convince them in vain.

Thus, the Reformists faced little resistance when they began to implement a fully algorithmic system. As a Reformist interviewee explained, the implementation involved several steps:

We began to distribute all our money through the [algorithmic] system. Not just half of it, but all of it. ... We also made our formula public. We explain how its components are derived.... Anyone can read it, so no one can get around the formula now.... We also refined the formula. If we knew costs would change in the future, we built that into the model. So it's also less justified to go around the formula. ... It is all very transparent now.

An audit report of the state accounting office issued in 2008 confirmed this account:

The distribution of public funds among the receivers [i.e., the subsidiaries] is controlled through a statistical model. The origin and direction of cash flows are transparent.... Less than 3 percent of funds are distributed on an ad hoc basis. Such ad hoc funds are dispensed in the case of an unexpected need for immediate operating needs.

In other words, actual funds became tightly coupled with the figures derived from the algorithmic system. What a Reformist interviewee called "a decade of culture wars" ended with the coupling of the formal algorithmic system and actual funding outcomes.

\section{DISCUSSION}

The findings I report above shed light on some of the intraorganizational processes that precede and follow a decision to decouple. In this section, I discuss these findings and develop two process models that formalize these data. I first present a model of the process that leads up to decoupling. This model describes a sequence of steps through which decoupling emerges. The second model, in turn, depicts a process that unfolds in the aftermath of decoupling. This model highlights a curious paradox, as it suggests that the very decision to engage in decoupling may trigger changes that eventually contribute to the erosion of decoupling.

\section{The Decision to Decouple: A Process Model}

My first research goal was to explore the process that leads up to the decision to decouple. Figure 1 depicts a probabilistic model of this process, which incorporates findings from the case of the Agency and insights from prior research. The left-hand column displays a sequence of four steps leading from the emergence of institutional pressures to decoupling. The right-hand column lists some of the moderating factors that affect (but do not fully determine) the probability that this process will move from one step to the next.

The first step in this process is the emergence or intensification of institutional pressures to adopt a particular organizational policy. In the face of such pressures, organizational decision makers evaluate the desirability of adopting the policy in form or in practice, or both (step 2). As the right-hand column indicates, several factors may enter this calculus, affecting the probability that the process moves to step 3. First, when decision makers expect that formally adopting an institutionally prescribed policy will confer a significant degree of legitimacy on their organization, or when they anticipate that outright noncompliance will lead to a significant loss of legitimacy, they will be particularly likely to regard the formal adoption of the policy as advantageous. In the case of the Agency, for example, as the Old Guard believed that failure to introduce an algorithmic system would undermine organizational legitimacy, they concluded that formally adopting such a system was inevitable.

At the same time, even when organizational decision makers recognize the need to adopt a policy formally, they may have reasons to resist its implementation in practice. One such reason, emphasized by Westphal and Zajac (2001), might be the policy's potential to threaten the economic interests or power of organizational leaders. For example, corporate executives might resist the actual implementation of incentive plans that would introduce compensation risk into their pay packages (Westphal \& Zajac, 1994).

Without denying the importance of economic interest and power-seeking behavior, the present study emphasizes another important reason why decision makers who find it advantageous to adopt a policy formally might nevertheless resist its im- 
FIGURE 1

A Road to Decoupling

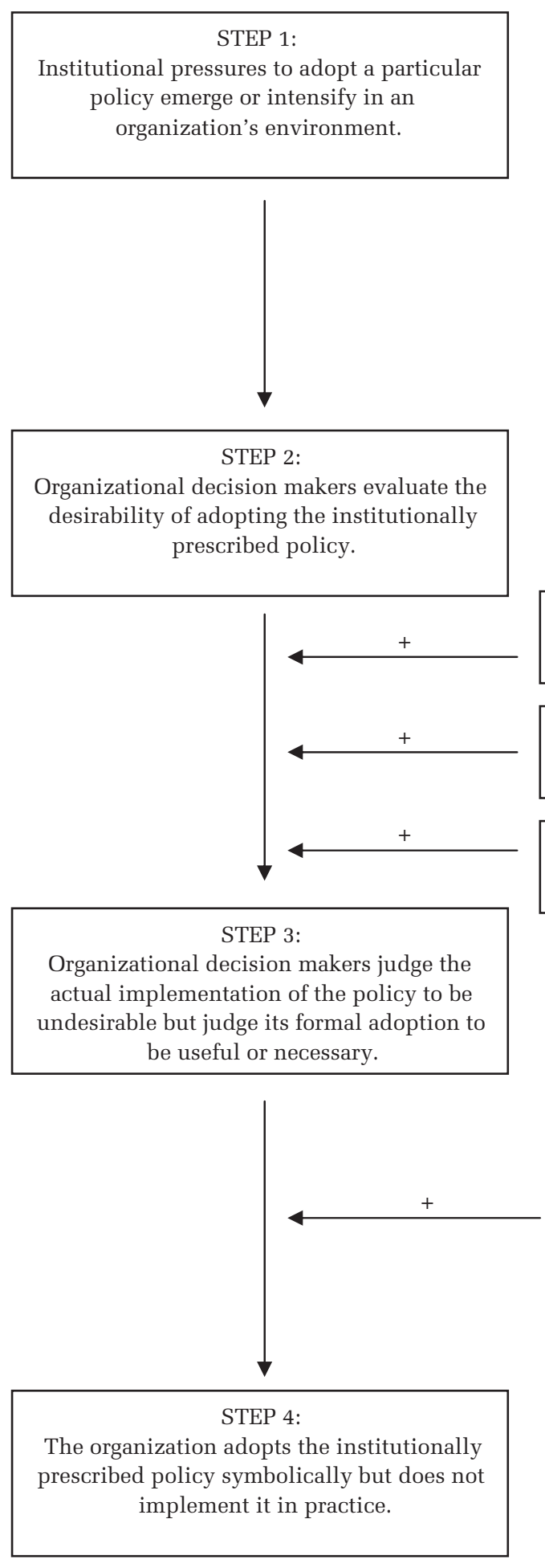

plementation in practice: inconsistency between the policy and the decision makers' ideological beliefs about how their organization should be run. In this case, since members of the Old Guard saw algorithmic budgeting as a threat to the core mis-
Extent to which the formal adoption of the policy is expected to maintain or enhance organizational legitimacy

Extent to which the actual implementation of policy would conflict with the interests of decision makers

Extent to which the actual implementation of policy would conflict with the ideology of decision makers
Extent to which the decision makers who regard decoupling as desirable have control over the organizational domain to which the policy is relevant sion of the Agency, they refused to implement it in practice. Although doing so did help to maintain the Old Guard's control over the allocation of funds, a narrow focus on power preservation would fail to address why the Old Guard insisted on pre- 
serving discretion over the particular domain of subsidiary finance. If simply interested in maintaining as much control as possible, why would these bureaucrats commit so much of their time and resources to this particular battle? That is, why was the Old Guard willing to loosen its control over some other domains-such as staff recruitment and public relations-but not this one? The answer lies, at least in part, in how the Old Guard interpreted this battle and its possible outcomes. Indeed, without understanding the ideological lens through which the Old Guard viewed the algorithmic system, one might expect them to have pursued a very different strategy: had they viewed the preservation of subsidiaries as a lower priority, they may well have focused on maintaining control over a different organizational domain.

Thus, knowing that members of the Old Guard were self-interested and sought to preserve their power would, in itself, do little to explain why they focused their efforts on subsidiary finance in particular. To develop a more satisfactory explanation, one must also understand the Old Guard's ideology, specifically the conviction that the subsidiaries were valuable pieces of national property that ought to be preserved. By putting high-cost subsidiaries in danger, algorithmic budgeting was inconsistent with this conviction and jeopardized the Old Guard's ability to fulfill their perceived duty. Once this ideological lens is understood, one can explain not only why the Old Guard resisted giving up its power in general but also why their resistance concentrated on the particular domain of subsidiary finance. Accordingly, my model indicates that ideological beliefs about how their organization should be run constitute a potentially important factor in motivating decision makers to engage in decoupling.

In step 3, on the basis of their ideology, interests, and the anticipated consequences of compliance and noncompliance, organizational decision makers judge the actual implementation of the policy to be undesirable but judge its formal adoption to be necessary or useful. Whether decision makers are able to translate this assessment into action depends on how much control they have over the organizational domain in which the policy is to be adopted. If-like the Old Guard-they have sufficient power to enforce their will in the relevant domain, the process reaches its final stage: the organization adopts the institutionally prescribed policy symbolically but decouples it from actual practices (step 4).

Comparison to previous studies. Although this model is broadly consistent with existing explanations of decoupling, it also highlights factors that have received relatively little previous attention. In line with Meyer and Rowan's (1977) explanation, for example, this model suggests that decoupling is a response to a conflict between institutional pressures and internal organizational considerations. Meyer and Rowan's account, however, treats an organization largely as a black box, giving little attention to how internal conditions affect the likelihood of decoupling. By contrast, the model presented here opens the organizational black box and suggests that decoupling is not carried out by a unified entity-"the organization"-but by particular decision makers who use their power to pursue their interests or ideological goals. As the struggle of the Old Guard and the Reformists demonstrates, whether an organization engages in decoupling depends on who has the power to shape the organization's practices and whether those in power prefer decoupling or not. Thus, although "internal considerations" do play a key role in decoupling, this model goes beyond Meyer and Rowan's account because it provides insight into the source of these considerations, suggesting that they reflect the ideology and interests of powerful organizational actors.

This model is also broadly consistent with Westphal and Zajac's (2001) interest-based account as it acknowledges that decoupling may occur not necessarily because it is functional for an organization but because it serves the goals of powerful organizational actors. Thus, the model presented here incorporates Westphal and Zajac's insights about the role of power and interests in decoupling. This model, however, also highlights another critical factor because it suggests that, in addition to economic interests and simple power-seeking behavior, ideology may also play a key role in motivating organizational actors to engage in decoupling. Accordingly, this model concurs with the findings of Coburn (2004) and Binder (2007), who suggested that the views and values of organization members influence whether a policy will be decoupled from practice. I emphasize, however, that ideology only affects the extent of decoupling if it is backed by power. Actors may have strong ideological reasons to support or oppose decoupling, but they can only act on these convictions effectively if they have control over the relevant organizational domain.

\section{From Decoupling to Coupling}

The second goal of my research was to explore the processes that unfold inside organizations after decoupling occurs. My findings suggested a chain of events, states, and mechanisms through which the process that follows decoupling may ultimately 
undermine decoupling itself. This model, presented in Figure 2, displays a sequence of five steps leading from the purely symbolic adoption of a formal policy to its actual implementation. The right-hand column lists a set of moderating factors that affect (but do not fully determine) the likeli- hood that the process will move from one step to the next.

Steps 1-3: Carriers of a competing ideology enter an organization. The first step in this model is the symbolic adoption of a formal policy. In the case of the Agency, since the symbolic adoption of

FIGURE 2

\section{From Decoupling to Coupling: A Process Model}

\section{Initial Response to Institutional \\ Pressures}

Demographic Change

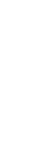

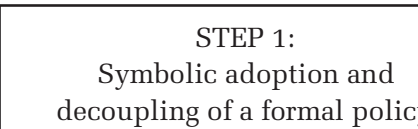

decoupling of a formal policy

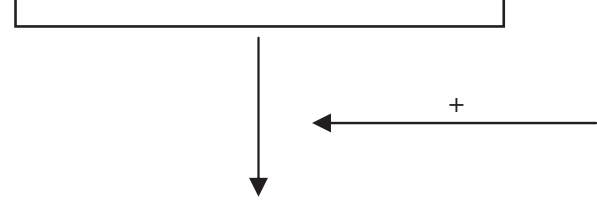

STEP 2:

Entry of new organizational members with skills to implement the formal policy

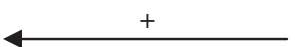

STEP 3:

Attempts by new organizational members to spread their vision of organizational rationality

Contest for
Organizational
Power

New Response to Institutional Pressures
Need for specialized skills and knowledge in the symbolic implementation of the policy
Professionalization of the practices involved in implementing the formal policy

Demographic transition (entries, exits, and promotions) that strengthen the new members

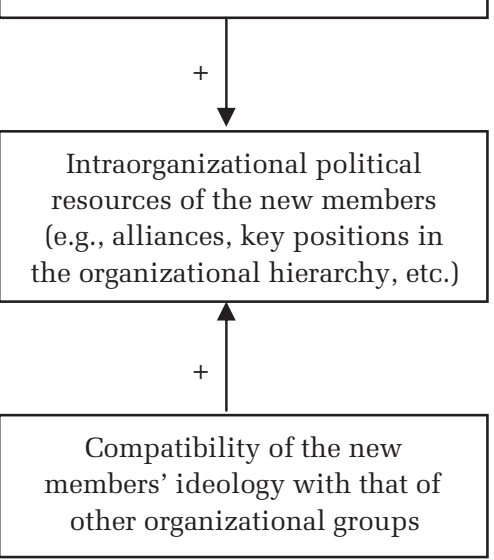


the algorithmic system required specialized skills that existing organization members did not have, it was necessary to bring new actors into the organization. Thus, the Agency's response to unwelcome institutional forces triggered a change in its demography (step 2). This change, however, was not only demographic but also ideological, because the new organization members brought with them an ideology that was inconsistent with the beliefs and values of existing members. Although the Old Guard's ideas about fund allocation were rooted in the institutional logic of Communist state bureaucracies, the Reformists' position reflected the logic of markets and modern economics. Thus, paradoxically, the Old Guard's efforts to resist the logic of markets and competition opened the Agency's door to carriers of that very logic.

Trained to implement the algorithmic system, the new organization members viewed it as rational and imbued it with meaning that they derived, in part, from the abstract knowledge in which their occupational training was grounded-modern economic theory and statistics. Imbued with such meaning, the implementation of the algorithmic system became more than just a job to the Reformists. In Max Weber's words, "an office is a vocation" and "entrance into an office is considered an acceptance of a specific duty of fealty to the purpose of the office" (1978: 958-959). The force of this fealty may be even stronger if the practices involved in the implementation of a formal policy are professionalized, as members of professional groups are "trained and socialized to promote the rules [and problem-solving approaches] that best define their professional identity" (Stryker, 2000: 196). Indeed, research has indicated that professional identities can become powerful guides and drivers of individuals' actions at work (Schein, 1978), and the desire to enact such identities is particularly strong in organizations that employ members of multiple occupations (Van Maanen \& Barley, 1984: 331-333). Accordingly, the Reformists attempted to fulfill the ideals of their office by advancing their vision of rationality within the organization. In doing so, they challenged the prevailing view of bureaucratic rationality and attempted to convince other organizational actors to couple actual practices with the formal policy (step 3). Thus, the Agency became a political battlefield where the competing institutional logics of market rationality and bureaucratic planning collided.

Steps 4-5: Shift in the dominant ideology and practice. The success of an attempt to gather support for, and eventually institutionalize, a new view of organizational rationality depends partly on the distribution of power within an organiza- tion. This distribution is not fixed and may change continually as a result of new alliance structures and changes in the organization's demography (entries, exists, and internal transitions, such as promotions). In this case, the changes in both demography and alliance structures favored the Reformists.

First, a demographic change- the wave of retirement that weakened the Old Guard-allowed the Reformists to rise to key positions in the formal hierarchy and thus extend their control over the Agency's funds. The importance of this change becomes clear if one considers what might have happened if powerful members of the Old Guard had not reached the mandatory retirement age in the early 2000s. In that case, the Old Guard could have probably preserved the senior positions that gave them direct control over much of the Agency's funds. In turn, if the Old Guard had maintained such control, the Reformists may not have had an opportunity to build all funds into the algorithmic system. Accordingly, my model suggests that demographic conditions strongly influence new actors' chances to realize their vision of how their organization should be run. This conclusion is akin to Thomas Kuhn's argument that scientific paradigm shifts are partly driven by demographic changes. In the words of Max Planck, quoted by Kuhn, "a new scientific truth does not triumph by convincing its opponents and making them see the light, but rather because its opponents eventually die" (1970: 151).

Second, the Reformists built alliances and enlisted supporters for a truly algorithmic system. They were particularly successful in doing so because they shared similar, or at least compatible, ideas about the funding of subsidiaries with several other actors in the organization. For example, by providing a common language and a shared set of ideas, modern economics helped the Reformists enlist allies among junior-level bureaucrats in other divisions of the Agency. By contrast, in the absence of a similar connection to junior employees, the Old Guard had no significant influence over that group. Thus, this model suggests that sharing compatible views of organizational rationality with other groups contributes to the ability of new actors to build alliances and, therefore, to compete successfully against an incumbent group.

Of course, intraorganizational power dynamics are not independent of broader institutional changes in society. For example, the fact that an increasing number of young employees had been exposed to modern economics before they entered the Agency undoubtedly reflected an increasing acceptance of the logic of markets in broader soci- 
ety. Crucially, however, this macrolevel change did not directly and automatically result in the coupling of policy and practice at the Agency. Although the broader spread of the market logic helped the Reformists by enhancing their ability to build alliances, its effect on other levers of power in the Agency seems to have been less significant. For example, it was not this broad institutional change, but the mandatory retirement age, that began to displace the Old Guard from their formal positions of authority. Thus, it seems that, rather than directly corresponding to changes in its institutional environment, changes in an organization's response to institutional pressures reflect the interaction of macroinstitutional forces and intraorganizational processes.

If the new members and their ideology indeed triumph in an organization, the process moves to step 4 . The final step, then, is alignment of the organization's practices with the preferences of the newly dominant group. Since this group aims to implement the formerly symbolic policy, their triumph results in the coupling of formal policy and actual practice (step 5). ${ }^{4}$ Thus, the final step in this model reveals the far-reaching ramifications of a decision to decoupleramifications that, paradoxically, may even lead to the erosion of decoupling. In the case of the Agency, these ramifications began to unfold precisely because the Old Guard hired the Reformists to produce symbolic documents that would underpin decoupling. In other words, in an attempt to preserve the status quo, the Old Guard inadvertently planted seeds of change when they brought the Reformists into the Agency. In the ensuing process, the organization's response to institutional pressures shifted gradually from decoupling to actual compliance with institutional prescriptions. The critical role of the Reformists in this shift illustrates what Stinchcombe (1997: 17-18) called the "guts of institutions"- that is, the notion that an institutional mandate only has power because some actors (in this case, the Reformists) care to hold their organization to a mandate.

The role of ideology. What motivated the Reformists to hold the Agency to the mandate of algorithmic budgeting and to challenge Old Guard? With hindsight, an interest- or power-based explanation may seem appealing. To be sure, when the Reformists rose to power, they were able to gain control over subsidiary finance and implement a

${ }^{4}$ Espeland (1994) and Hallet (2007) used the term "recoupling." I omit the prefix "re-" because it implies that policy and practice came to be coupled again. In this case, however, the algorithmic system was never previously coupled with actual practices. policy that made use of their technical skills. It seems, however, that focusing exclusively on economic interests or organizational power seeking would have been insufficient in predicting the Reformists' actions a priori. The Reformists entered the Agency as young employees who lacked experience, allies, and key positions in the organizational hierarchy. Yet they challenged the dominant view of how things should be done and risked confrontation with a much more powerful group. Could this course of action have been predicted with reasonable certainty if one had known only that the Reformists pursued their interests? It seems doubtful. Without any knowledge about the Reformists' ideology of progress and efficiency, a prognosticator may well have expected these new and organizationally weak employees to choose a risk-averse path and simply perform the tasks assigned to them, or even to accept the Agency's traditional values. But, once one understands the importance of algorithmic budgeting in the Reformists' ideology, predicting their active resistance to decoupling becomes significantly easier. Tellingly, even members of the Old Guard were initially surprised at the Reformists' resistance-but only until they understood the "neoliberal mentality" of these young employees.

Similarly, without understanding the ideas of the two high-ranking appointees who joined the Agency in the late 1990s, one could hardly explain why these appointees decided to support a fully algorithmic system. These actors occupied similar positions in the Agency's hierarchy as members of the Old Guard and were similarly unfamiliar with quantitative modeling. Yet they formed a coalition with a relatively weak group of young employees and supported the algorithmic system. This decision, however, would only be unexpected if one did not know how much emphasis these actors put on streamlining international operations. Once this guiding principle is understood, it is no longer a surprise that the two new appointees supported a truly algorithmic system. Thus, the cases of the Old Guard, the Reformists, and the two senior appointees all suggest that explaining why a given group supports or opposes decoupling requires taking into account not only the group's material interests and desire for power, but also the group members' shared beliefs about how their organization should be run.

\section{CONCLUSION}

\section{Implications for Institutional Theory}

Two research questions guided this study. First, how does the process that leads up to decoupling 
unfold inside organizations? Second, what happens within organizations over time after decoupling occurs? I developed two models in response to these questions. The first model focuses on events and decisions that precede decoupling (Figure 1). The second model describes how the process that follows the decision to decouple may eventually lead to the coupling of policy and practice (Figure 2). Most directly, these models contribute to understanding of decoupling by describing how decoupling unfolds over time and specifying the factors that play a role in that process. The first model enriches existing theory by drawing attention to the role of ideology in determining whether powerful organizational actors will attempt to decouple policy and practice. The second model contributes to understanding by showing that the decision to decouple may have far-reaching ramifications that, over time, may even undermine decoupling. Although previous research has noted the possibility that decoupling will be undone (Espeland, 1998), this model goes one step further and suggests that, ironically, the coupling of policies and practices may result from changes that are triggered, in part, by the initial decision to decouple.

In addition to their direct contributions to understanding of decoupling, these models also have broader implications for institutional theory. First, both models suggest that intraorganizational conditions have a powerful effect on how organizations respond to their institutional environment. This is a noteworthy point because existing research has often focused on the environmental, rather than internal, determinants of how organizations respond to institutional mandates. Oliver, for example, suggested that organizational responses to institutional pressures "are predictable largely in terms of the nature of the institutional pressures themselves" (1991: 174; emphasis added). Without denying the relevance of institutional forces, this study suggests that it is also critical to understand how powerful actors inside an organization perceive those forces. Thus, to understand organizational responses to institutional pressures, a researcher must explore the competing ideas and interests of individuals within organizations, rather than treating organizations as unified entities. In this sense, this study enriches institutional theory with the notion-central to organizational demography-that organizational behavior reflects "the values and cognitive bases of powerful actors in the organization," which in turn are influenced by intraorganizational demographic phenomena (Hambrick \& Mason, 1984: 193).

Second, this study suggests that, when an organization's internal conditions change, its response to institutional pressures may change as well. Thus, an organization's response to a given institutional mandate is not necessarily constant: it may change dramatically over time, even if the mandate itself remains the same. The Agency's response, for example, shifted over time from circumventing an institutional mandate to complying with it. To date, little attention has been given to this possibility because extant research has tended to describe how a particular institutional mandate triggered an organizational response at a given time. I suggest that the relationship between institutional pressures and organizational behavior is more complex because, over time, an organization may adopt several different responses to the same institutional mandate. Thus, responding to institutional pressures should be seen as a dynamic, evolving phenomenon. Clearly, demographic processes and intraorganizational struggles continually cause organizations to change, often incrementally and sometimes radically. As a result, an organization that complied with institutional pressures a year ago may resist them today, and an organization that used to circumvent a mandate may have embraced it by now. Thus, rather than examining responses to institutional pressures at a single point in time, researchers should study these responses and the actors who implement them in motion, exploring how responses are formulated, contested, and altered over time.

Third, although existing research has documented the various ways in which organizations may respond to institutional pressures, from blind adherence to active resistance (Oliver, 1991), scholars have given less attention to how the execution of each of these responses affects organizations. My findings suggest that this lack of attention is regrettable because enacting a response to institutional pressures may have profound organizational consequences. In the case of the Agency, for example, the impact of institutional pressures was far greater than simply triggering an organizational response (decoupling), because that very response led to the entry of new actors, who in turn caused still more changes in the organization. This finding suggests that, to understand the full extent to which institutions shape organizations, one should explore not only an organization's immediate response to institutional pressures, but also the long-term ramifications of the response itself. Clearly, responding to institutional pressures often requires much more substantial changes than simply rewriting a mission statement or a code of conduct. For example, to display compliance with institutional mandates even symbolically, organizations may need to create new departments, recruit new employees, hire 
professional consultants, or purchase new technologies (Meyer \& Rowan, 1977). Clearly, such changes are far from trivial, and over time their consequences may extend well beyond their immediate impact. As the case of the Agency demonstrates, even a relatively small initial change in an organization's demography-the entry of a few new employees-may have profound long-term consequences. If these indirect consequences of responding to institutional pressures were neglected, one would fail to appreciate the full extent to which institutional forces affect organizations.

To summarize, my findings suggest that organizational responses to institutional pressures shape and are shaped by processes inside organizations. First, intraorganizational conditions-such as the distribution of power, the contest of interest groups, and the nature of ideological dividesshape how an organization responds to institutional pressures. Second, as these conditions change, the organization's response to institutional pressures may change as well. Finally, these responses themselves are sources of organizational change because they may have far-reaching, unforeseen ramifications.

\section{Implications for Practice}

Responding to new institutional forces is an important challenge for many organizations. For example, when laws and regulations change, or when an organization begins to operate in a country with unfamiliar rules and norms, managers must decide how to handle newly encountered expectations about particular organizational policies. One possible response is to adopt institutionally prescribed policies formally and then decouple them from everyday routines. Managers may pursue this strategy to satisfy external constituents while allowing organizational activities to go on as before. In other cases, however, managers may prefer actual compliance, perhaps because they believe in the usefulness of the policy or are concerned that decoupling would be revealed. This study has implications for both of these situations.

For managers who aim to avoid institutional pressures through decoupling, my findings offer a cautionary tale. Most importantly, decoupling a policy from actual practice may be an unsustainable strategy in the long run if some actors in the organization are deeply invested in the policy. These actors may be present in the organization in the first place or may enter when the policy is symbolically adopted. As this case showed, even if these actors are initially weak, they may accumulate sufficient power over time to do away with decoupling and put the policy into practice. Thus, the merely symbolic adoption of a policy is more likely to be sustainable if it does not require the entry of individuals who are committed to implementing the policy. If the entry of such actors is inevitable, or if they are already present in the organization, other avoidance strategies (Oliver, 1991)_such as co-opting constituents or openly confronting institutional demands-may be more successful than decoupling.

My findings offer the same basic lesson to managers who aim to ensure actual compliance with institutional prescriptions: To implement a policy substantively, an organization needs individuals with both motivation and power to carry out the policy in everyday practice. Thus, the implementation of a policy is more likely to succeed if powerful actors within the organization are specifically charged with implementing the policy and have an incentive or an ideological motivation to do so. This qualitative finding is consistent with existing quantitative evidence. For example, researchers have found that appointing specialized diversity officers is much more effective at increasing diversity than simply adopting diversity training or evaluation programs (Kalev, Dobbin, \& Kelly, 2006).

This lesson is also important for policy makers who seek to influence the behavior of organizations. Examples of failed top-down organizational reforms abound, from economic reform in developing countries (Easterly, 2008) to school reform in the United States (Lusi, 1997). As Peng noted, international organizations, such as the World Bank and the IMF, often focus on statelevel reforms and operate on "the naive belief that competitive strategies will 'naturally' emerge" within organizations. Yet, in reality, organizations "often do not behave as reformers and their foreign advisors hoped they would" (2003: 277). My models suggest that institutional prescriptions are most likely to affect organizations substantively when they are consistent with the interests and ideology of powerful organizational actors. Thus, even strong institutional pressures may be ineffective if key organizational actors do no support the mandate in question. In such cases, policy makers should strengthen organizational actors who already support implementation and should make the institutional mandate attractive to other organizational actors, either by creating incentives for implementation or by communicating the mandate's benefits in terms that are meaningful to these actors. 


\section{Limitations and Future Research}

This study, of course, has its limitations, some of which provide opportunities for further research. A major limitation is that this research was conducted in a single organization. Thus, it was beyond the scope of this study to analyze how the processes of decoupling might vary in different settings. This study aimed to generate and extend theory, and further research is necessary to test the proposed models in other settings, including private companies in Western market economies. Clearly, a bureaucratic state organization differs from a private enterprise in its specific goals, constituents, and governance structures. Moreover, the institutional context of a post-Communist country differs significantly from that of a Western capitalist nation. Thus, although it is unlikely that the most basic processes of decoupling differ fundamentally in other types of organizations, the details and generalizability of the proposed models remain to be tested. Indeed, there may be more than just one path to decoupling and to subsequent coupling, and studying organizations that are significantly different from the Agency may reveal such alternative paths. A useful strategy in such research would be to find opportunities for observing the decoupling decision more directly than I was able to do in this study.

A further limitation is that this study focused on just one possible response to institutional pressures: decoupling. The repertoire of possible responses, however, is wide: it ranges all the way from blindly accepting required mandates to actively manipulating institutional pressures (Oliver, 1991). Since this study highlighted how the consequences of decoupling may begin a life of their own, an obvious direction for future research is to explore the organizational consequences of other responses. For example, what might be the indirect or unforeseen organizational effects of directly confronting institutional pressures? How does co-optation-such as putting institutional constituents on an organization's board of directors-affect an organization beyond this immediate demographic and political change? In general, what kind of internal processes may be triggered when an organization complies with institutional pressures and begins to devote considerable resources to a previously neglected activity? Answering these questions would result in a more complete understanding of the extent to which institutions shape organizations. More fundamentally, this study suggests that organizational behavior in the face of institutional pressures is a truly multilevel phenomenon that should be understood with reference to macrolevel institutional forces, organization-level responses, and intraorganizational dynamics. A systematic analysis of these three levels should yield a deep understanding of how institutional forces shape the behavior of organizations.

\section{REFERENCES}

Berliner, J. 1957. Factory and manager in the USSR. Cambridge, MA: Harvard University Press.

Binder, A. 2007. For love and money: One organization's creative and multiple responses to a new funding environment. Theory and Society, 36: 547-571.

Coburn, C. 2004. Beyond decoupling: rethinking the relationship between the institutional environment and the classroom. Sociology of Education, 77: 211244.

Easterly, W. 2008. Institutions: top down or bottom up? American Economic Review, 98(2): 95-99.

Eisenhardt, K. M. 1989. Building theories from case study research. Academy of Management Review, 14: 532-550.

Elsbach, K. D., \& Sutton, R. I. 1992. Acquiring organizational legitimacy through illegitimate actions: A marriage of institutional and impression management theories. Academy of Management Journal, 35: 699-738.

Espeland, W. 1998. The struggle for water: Politics, rationality, and identity in the American Southwest. Chicago: University of Chicago Press.

Gephart. B. 2004. Qualitative research and the Academy of Management Journal. Academy of Management Journal, 47: 454-462.

Granick, D. 1961. The red executive: A study of the organisation man in Russian industry. New York: Anchor.

Hallett, T. 2010. The myth incarnate: Recoupling processes, turmoil, and inhabited institutions in an urban elementary school. American Sociological Review, 75: 52-74.

Hambrick, D. C., \& Mason, P. A. 1984. Upper echelons: The organization as a reflection of its top managers. Academy of Management Review, 9: 193-206.

Kalev, A., Dobbin, F., \& Kelly, E. 2006. Best practices or best guesses? Diversity management and the remediation of inequality. American Sociological Review, 71: 589-917.

Kornai, J. 1992. The socialist system: The political economy of communism. Oxford, U.K.: Clarendon Press.

Kuhn, T. 1970. The structure of scientific revolutions. Chicago: University of Chicago Press.

Ledeneva, A. 1998. Russia's economy of favors: Blat, networking and informal exchange. Cambridge, U.K.: Cambridge University Press.

Lusi, S. F. 1997. The role of state departments of edu- 
cation in complex school reform. New York: Teachers College Press, Columbia University.

Maxwell, J. 1996. Qualitative research design: An interactive approach. Thousand Oaks, CA: Sage.

McCarthy, D., Puffer, S., May, R. C., Ledgerwood, D., \& Stewart, W. 2008. Overcoming resistance to change in Russian organizations: The legacy of transactional leadership. Organizational Dynamics, 37(3): 221235.

Meyer, J. W., \& Rowan, B. 1977. Institutionalized organizations: Formal structure as myth and ceremony. American Journal of Sociology, 83: 340-363.

Meyer, J. W., \& Rowan, B. 1978. The structure of educational organizations. In M. W. Meyer (Ed.), Environments and organizations: 78-109. San Francisco: Jossey-Bass.

Miles, M., \& Huberman, M. 1994. Qualitative data analysis. Newbury Park, CA: Sage.

Oliver, G. 1991. Strategic responses to institutional processes. Academy of Management Review, 16: 145179.

Peng, M. W. 2003. Institutional transitions and strategic choices. Academy of Management Review, 28: 275-96.

Pettigrew, A. M. 1990. Longitudinal field research on change: Theory and practice. Organization Science, 1: 267-292.

Puffer S., \& McCarthy, D. 2007. Can Russia's state-managed, network capitalism be competitive? Institutional pull versus institutional push. Journal of World Business. 42(1): 1-13.

Schein, E. H. 1978. Career dynamics: Matching individual and organizational needs. Reading, MA: Addison-Wesley.
Schofer, E., \& Hironaka, A. 2005. The effects of world society on environmental protection outcomes. Social Forces, 84: 25-47.

Scott, R. W. 2008. Institutions and organizations. Thousand Oaks, CA: Sage.

Stinchcombe, A. 1997. On the virtues of the old institutionalism. In J. Hagan \& K. S. Cook (Eds.), Annual review of sociology, vol. 23: 1-18. Palo Alto, CA: Annual Reviews.

Stryker, R. 2000. Legitimacy processes as institutional politics: Implications for theory and research in the sociology of organizations. In S. Bacharach \& E. Lawler. (Eds.), Research in the sociology of organizations, vol. 17: 179-223. Greenwich, CT: JAI Press.

Van Maanen, J., \& Barley, S. R. 1984. Occupational communities: Culture and control in organizations. In B. M. Staw \& L. L. Cummings (Eds.), Research in organizational behavior, vol. 6: 287-365. Greenwich, CT: JAI Press.

Weber, M. 1978. Economy and society ed. [G. Roth \& C. Wittich, Eds. \& Trans.]. Berkeley: University of California Press.

Westphal, J. D., \& Zajac, E. J. 1994. Substance and symbolism in CEOs' long-term incentive plans. Administrative Science Quarterly, 39: 367-390.

Westphal, J. D., \& Zajac, E. J. 2001. Explaining institutional decoupling: The case of stock repurchase programs. Administrative Science Quarterly, 46: 202228.

White H. 1970. Chains of opportunity: System models of mobility in organizations. Cambridge, MA: Harvard University Press.

Yin, R. K. 1984. Case study research: Design and methods. Beverly Hills, CA: Sage.
András Tilcsik (tilcsik@fas.harvard.edu) is a doctoral candidate in organizational behavior at Harvard University. His research focuses primarily on organizational change, the hiring process, corporate social practices, and the performance of teams and individuals within organizations.

This article continues with 4 appendixes. 


\section{APPENDIX A}

\section{FIGURE A1}

\section{Simplified Organizational Chart of the Agency ${ }^{a}$}

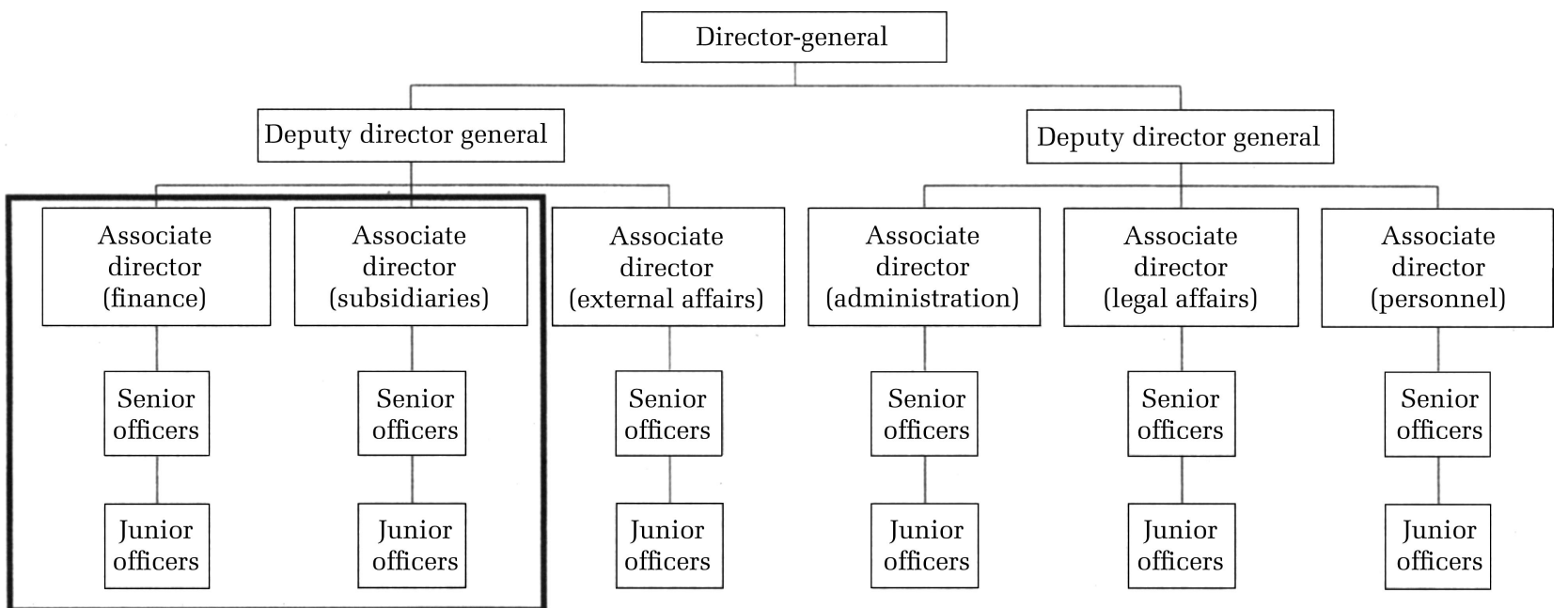

a This chart reflects the situation in 2003 and does not include secretarial and other support staff. The frame indicates organizational units that have responsibilities related to the funding of subsidiaries.

APPENDIX B

Protocol for Identifying the Sample of Interviewees

\section{Introductory, Open-Ended Questions}

1. Can you describe in specific detail how public funds are allocated among the subsidiaries?

2. What is your role in the allocation process?

\section{Probing and Clarifying Questions (by Role)}

1. Can you name all the people who are involved in deciding about the allocation and in executing those decisions? I'd like to have a list of those people.

2. Tell me about the role of [each of the mentioned individuals].

3. Tell me about the role of [each individual who was mentioned by other informants.]

4. Based on your answers, I drew this simple organizational chart. Is this correct? Am I missing anyone?

\section{Probing and Clarifying Questions (by Step)}

1. Can you walk me through, step-by-step, how allocation decisions are made?

2. What is the very first step? Who is involved in it? What happens afterwards?

3. What time of the year does the allocation process begin? Tell me what happens in this process in each of the following months of the year.

\section{Changes over Time}

1. Had any of the people you mentioned played a different role in this process in the past? [Remind the informant of the individuals he or she mentioned]

2. Is there anyone who used to play a part in this process but left the Agency already? 


\section{APPENDIX C \\ FIGURE C1}

\section{Decision Makers with Direct Responsibilities over Fund Allocation, 1997 and $2007^{\mathrm{a}}$}
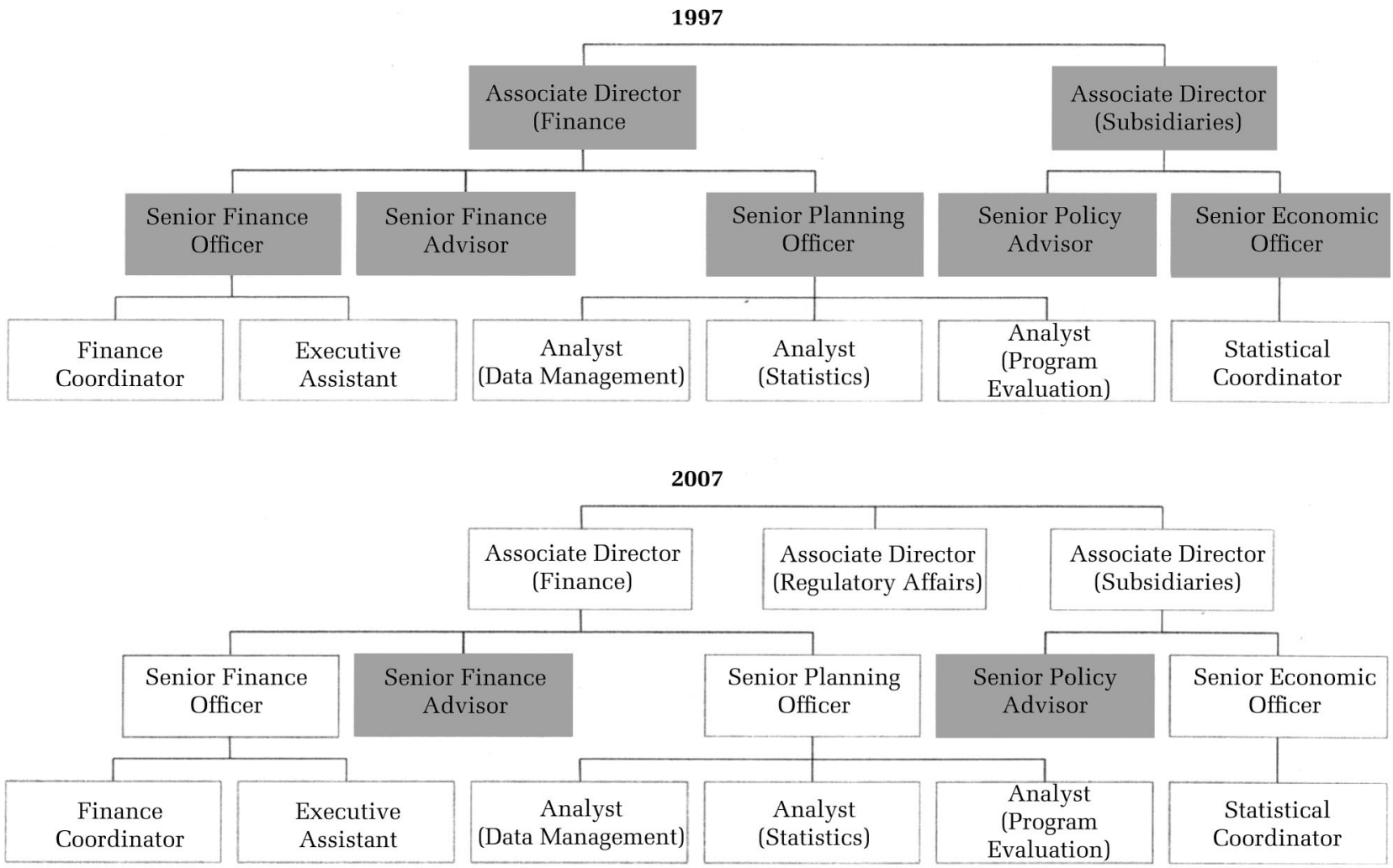

${ }^{\text {a }}$ Gray boxes indicate that in the given year the position was filled by an employee who had joined the Agency during the Communist era (i.e., before 1990). This chart does not include secretarial positions with no decision-making power.

\section{APPENDIX D}

Interview Protocol for Agency Employees

I. Introductory Questions

1. Tell me about what the Agency does. Can you tell me about the Agency's history?

1. Which unit of the Agency do you work at? What is your position?

2. What does your unit do? Which other units does it work closely with?

3. What does your job entail?

4. Did you hold a different position in the past? What was your responsibility then?

5. When did you join the Agency? Where did you work before? When did you graduate from university? What did you study?

\section{Questions about Fund Allocation Practices}

Current system

6. I am interested in how public funds are allocated among the subsidiaries. Tell me about how the Agency funds these subsidiaries.

7. Can you describe in specific detail how the funds are actually allocated? I am interested in the details of how it is actually done in practice, not just how it supposed to be done on paper.

8. Is this system in practice any different from the way it is on paper? If so, why do you think it is different? Can you recall when it became different from the system on paper? Can you walk me through just how that happened? How did those events affect this organization?

9. What do you think about this allocation system?

Changes

10. You joined the Agency in [year]. How were then the funds allocated in practice? On paper?

11. Has this funding system changed at all over the years? If it has, how? What are the differences?

12. When did the changes occur? Can you recall the events the led to these changes? What happened after [described event]?

13. Why was there a change?

14. Who changed the system? Why? What was their motivation?

15. How did those changes affect this organization?

16. What do you think of these changes? How do you think the funds should be allocated?

\section{Clarifying and Probing Questions}

Ask for elaborations as well as concrete incidents and examples that led to the respondent's generalized statements (e.g., Why do you say that? What do you mean by [phrase]? Could you walk me through just what happened [during mentioned event]? Can you give me an example?) 